RESEARCH ARTICLE

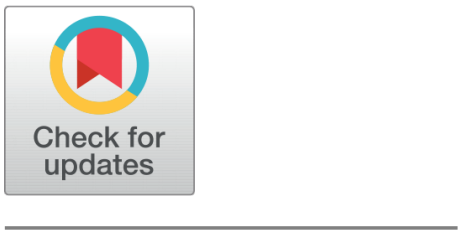

OPEN ACCESS

Received: 19.05 .2020

Accepted: 24.12 .2020

Published: 15.05 .2021

Citation: Buslig SMCA (2021) The Employability of the Graduates of Bachelor of Public Administration of Kalinga-Apayao State College from 2011-2013: A Tracer Study. Indian Journal of Science and Technology 14(17): 1392-1397. https://doi.org/ 10.17485/IJST/v14i17.633

* Corresponding author.

Tel: +639273766593

sheilamaecarol@yahoo.com

Funding: None

Competing Interests: None

Copyright: (c) 2021 Buslig. This is an open access article distributed under the terms of the Creative Commons Attribution License, which permits unrestricted use, distribution, and reproduction in any medium, provided the original author and source are credited.

Published By Indian Society for Education and Environment (iSee)

ISSN

Print: 0974-6846

Electronic: 0974-5645

\section{The Employability of the Graduates of Bachelor of Public Administration of Kalinga-Apayao State College from 2011-2013: A Tracer Study}

\author{
Sheila Mae Carol A Buslig ${ }^{1 *}$ \\ 1 Kalinga State University, Tel.: +639273766593
}

\section{Abstract}

Objectives: To describe the alumni profile in terms of the number of graduates, occupation type, the status of employment, government examination, and job-hunting period; and to determine the factors affecting their employment. Methods/Statistical analysis: The study utilized a descriptive-relational research design to aid a "one-shot survey"(1) in tracing the respondents. The 73 college graduates of school years 2011 to 2013 were the respondents. They were traced based on the Alumni Directory, enrollment forms, personal network, and key resource persons' use to inquire about current addresses. An online registration system was developed by Mr. Giarhard Awis, KASC Alumni Directory ${ }^{(2)}$ that graduates can log-on and fill up the survey forms. Findings: The study showed that 41 of the respondents are employed in public and private institutions, and 5 are permanent. Thirteen (13) were casual, and 23 works as contractual, 9 are unemployed, but some pursued graduate studies and manages their businesses. The respondents perceived that indicators "Eligibility," "Work experience related to the job," and "agency preferences" got a weighted mean of 2.20 described as moderately affect". The study further reveals 20 of 73 respondents can secure a job right after graduation. While 18 got employed 2 years after graduation. It is recommended that the graduates have to enroll in review classes for Civil Service examination and other government examinations for job eligibility. Graduates have to attend seminars, training, and workshops aligned to their field of interest to have more orientation on the agency they prefer for employment. They will further their studies by enrolling in their Master of Public Administration to strengthened/enhance more their educational qualification that may invite employment. Novelty/Applications: It assessed the availability and quality of graduates. It traced in what field the graduates' work-match/mismatch. It traced what competencies graduates use most in their world to provide information for higher education evaluation.

Keywords: Employability; Tracer Study; Graduates; Employment 


\section{Introduction}

The Bachelor of Public Administration of the Kalinga-Apayao State College had its first graduates on April 5, 2003 as confirmed by BOT Res. No. 410. It was offered as a degree program under the College of Arts and Sciences (CAS) which offered Bachelor of Arts major in Political Science and Public Administration, Bachelor of Science in Biology and Psychology.

In line with the recommendation of the Commission on Higher Education (CHED) to pool all related courses into one college the CAS was turned into Institute of Arts and Sciences on June 2006. By this time, the Bachelor of Arts major in Public Administration became Bachelor of Science in Public Administration authorized by BOT Res. No. 607, s. 2007. On June 2013, the Bachelor of Science in Public Administration was transferred to the main campus (Bulanao) and merged to B.S. in Criminology forming now the Institute of Criminal Justice Education and Public Administration (ICJEPA). At present the program is operating under CMO No. 06, s. 2010 and BOT Res. No. 828 s. 2011 naming the program Bachelor of Public administration $^{(3)}$. By December 2015, this program will be accredited to its level 2 by the Accrediting Agency of Chartered Colleges and Universities in the Philippines (AACCUP). This continuing growth of the Bachelor of Public Administration is brought about by the increasing needs and development challenges of local communities. The following are the program objectives (BOT Res. No. 828 s. 2011):

- To provide relevant knowledge in the field of Public Administration that is responsive to the needs and development challenges of local communities, the region and the nation as a whole thru advanced quality of instruction towards excellence;

- To train the students to become competent Public Administrators who are imbued with positive leadership, serviceorientedness, nationalism, democratic, dedicated and globally competitive agents of change; and

- To develop in the students, the leadership and management skills and other appropriate abilities such as efficiency and effectiveness in administering public affairs, ability to think critically and make objective and sound decisions and expertise in public affairs and management.

\section{Materials and Methods}

The study utilized a descriptive-relational research design with the aid of a "one shot survey". The target group for the tracer study included graduates of the year 2011 to 2013 of Kalinga-Apayao State College. The respondents comprised all the 73 graduates of the College which is included in the above-mentioned range of years. The identification of the graduate was primarily based on a list of graduates provided by the Alumni Directory on all graduates of that period. Through this list names and addresses of most of the graduates were available from the date of enrollment. However, it appeared necessary to follow up on contact addresses of all students in order to update their address details due to the possibility of movements since many students now have graduated and changed their contact addresses. First; all students were traced through there enrollment forms when still studying. The personal contact was expected to get many positive responses as well as encouraged the graduates to participate in the study and, moreover, to identify the remaining group of students. Second, personal network (word of mouth) and use of key resource persons from each group were used to inquire current addresses on those students who could not be traced through the previous method. Thirdly, an online registration system will be developed such that graduates who have internet connectivity can log-on and fill up the survey forms on-line in addition to the available existing questionnaire which is downloadable from the link for KASC alumni survey.

\begin{tabular}{cl}
\multicolumn{2}{c}{ Table 1. Population of the study } \\
\hline Year & Number of Graduates \\
\hline 2011 & 20 \\
2012 & 22 \\
2013 & 31 \\
Total & 73 \\
\hline
\end{tabular}

\section{Results and Discussion}

\section{Profile of the Bachelor of Public Administration}

This section presents the profile of the Bachelor of Public Administration graduates from school year 2011-2013 as to status of employment, type of employment, examination taken and length of time seeking for a job. 
Table 2 presents employment rate of the graduates of Bachelor of Public Administration. The table shows that 41 or $56.16 \%$ of 2011-2013 graduates of Bachelor of Public Administration of KASC are employed to both public and private institutions while the remaining 32 or $43.84 \%$ were unemployed but some of them are taking master's degree, others studied law and vocational courses and some furthered studies like taking education units. Some are self-employed, and they manage their own businesslike stores, networking business and farming.

Table 2. The Employment Rate of the Graduates of Bachelor of Public Administration.

\begin{tabular}{llll}
\hline Indicator & Frequency & Percentage & Rank \\
\hline Employed & 41 & $56.16 \%$ & 1 \\
Unemployed & 32 & $43.84 \%$ & 2 \\
Total & 73 & $100 \%$ & \\
\hline
\end{tabular}

Table 3 presents the respondents' type of employment of the graduates of Bachelor of Public Administration. The table shows that there are 18 who worked in public offices including public schools. There are 23 who worked in public offices including public school teachers or tutors. It is very evident that more graduates of Bachelor of Public Administration work in private institution.

Table 3. Type of Employment

\begin{tabular}{llll}
\hline Type of Employment & Frequency & Percentage & Rank \\
\hline Public & 18 & $44 \%$ & 2 \\
Private & 23 & $56 \%$ & 1 \\
Total & 41 & $100 \%$ & \\
\hline
\end{tabular}

Table 4 shows the Status of Employment of the graduates of Bachelor of Public Administration. There are 8 graduates with $19.51 \%$ who are permanent in status. There are 12 graduates with $29.27 \%$ who are in casual status and 21 graduates with $51.22 \%$ who are still in contractual status.

Table 4. Status of Employment

\begin{tabular}{llll}
\hline Status of Employment & Frequency & Percentage & Rank \\
\hline Permanent & 8 & $19.51 \%$ & 3 \\
Casual & 12 & $29.27 \%$ & 2 \\
Contractual & 21 & $51.22 \%$ & 1 \\
Total & 41 & $100 \%$ & \\
\hline
\end{tabular}

Table 5 presents the data on the professional examination taken by the graduates of Bachelor of Public Administration. The table shows there were 4 graduates with $9.76 \%$ who have taken the professional Civil Service examination, 2 graduates with $4.88 \%$ have taken the NaPolCom/SAF examination. There were 67 graduates or $85.36 \%$ who have not taken any examination for employment.

Table 5. Examination taken by the graduates of Bachelor of Public Administration.

\begin{tabular}{llll}
\hline Government examination & Frequency & Percentage & Rank \\
\hline Civil Service & 4 & 9.76 & 2 \\
NaPolCom/SAF & 2 & 4.88 & 3 \\
None & 67 & 85.36 & 1 \\
Total & 73 & $100 \%$ & \\
\hline
\end{tabular}

The Table 6 shows the length of job hunting by the graduates of Bachelor of Public Administration. The table shows that 20 graduates with $48.78 \%$ who found job below one year after graduation. There were 18 or $43.9 \%$ who found job in just one year to below two years after graduation. There were no graduates who have been hunting job for three year to below two years after. 
Table 6. Length of Job Hunting

\begin{tabular}{llll}
\hline Hunting period & Frequency & Percentage & Rank \\
\hline Below one year after graduation & 20 & $48.78 \%$ & 1 \\
One year to below two years after graduation & 18 & $43.9 \%$ & 2 \\
Two year to below two years after graduation & 3 & $7.32 \%$ & 3 \\
Three year to below two years after graduation & 0 & 0 & $100 \%$ \\
\hline Total & 41 & \\
\hline
\end{tabular}

Table 7 shows the factors affecting the employment of the graduates of Bachelor of Public Administration. The table shows that the obtained total average weighted mean was 2.20 which fall into the descriptive equivalence of moderately affected.

Table 7. Factors Affecting Employment of Graduates

\begin{tabular}{|c|c|c|c|c|c|c|}
\hline INDICATORS & MA (3) & MoA (2) & LA (1) & Wtd Mean & Rank & $\mathrm{DE}$ \\
\hline 1. Interest on the job & $12(36)$ & $21(42)$ & $40(40)$ & 1.62 & 7 & LA \\
\hline 2. Eligibility & 39 (117) & $25(50)$ & $9(9)$ & 2.41 & 1 & MA \\
\hline 3. Skills required by the job & $34(102)$ & $21(42)$ & $18(18)$ & 2.22 & 4 & MoA \\
\hline 4. Work experience related to the job & $43(129)$ & $17(34)$ & $13(13)$ & 2.41 & 1 & MA \\
\hline 5. Job opportunity & $38(114)$ & $21(42)$ & $14(14)$ & 2.33 & 2 & MoA \\
\hline 6. Job orientation and experience & $35(105)$ & $19(38)$ & $19(19)$ & 2.22 & 4 & MoA \\
\hline 7. Political interference in the appointment of employees & $35(105)$ & $23(46)$ & $15(15)$ & 2.27 & 3 & MoA \\
\hline 8. Agency preferences & $40(120)$ & $23(46)$ & $10(10)$ & 2.41 & 1 & MA \\
\hline 9. Finances in the job hunting & $29(89)$ & $20(40)$ & $24(24)$ & 2.07 & 5 & MoA \\
\hline 10. Information on job vacancies & $28(84)$ & $16(32)$ & $29(29)$ & 1.99 & 6 & MoA \\
\hline
\end{tabular}

Indicator 2 "Eligibility" got the highest weighted mean on the factors affecting employment. It reveals that many graduates are unemployed because they lack eligibility, or it is because they are not properly equipped for the job.

Indicator 4 "Work experience related to the job" obtained an average weighted mean of 2.41 described as "much affected". This means that many of the graduates lack experiences related to their job that is why they are not easily hired.

According to Wilbur Guidangen, a graduate of Public Administration "the solution can be found at different levels. College/universities need to start incorporating more experiential learning and encouraging the students to go out and seek opportunities rather than to rely on the qualification to do all the work for them".

Indicator 8 "Agency preferences" is also one of the highest weighted mean of 2.41 which described as "much affected". This means that some of the graduates applied to agencies for job, but they were not chosen because these agencies preferred graduates that are related to their agency.

Indicator 5 "Job opportunity" came next and obtained an average weighted mean of 2.33 described as moderately affected". This means that many of the graduates seeks job, but they cannot easily find one.

Indicator 7 "Political interference in the appointment of employees" which is the third rank obtained an average weighted mean of 2.27 as described as "moderately affected". Indicator 3 "Skills required of the job" and "Orientation and experienced on the job" which is the rank 4 obtained an average weighted mean 2.22 described as "moderately affect".

Indicator 9 "Finances to be used in looking for job" which is rank 5 obtained an average weighted mean 2.07 described as "moderately affected".

Indicator 1 "Interest on the job" obtained the lowest mean of 1.62 with a descriptive equivalence "less affected". Some graduates of Bachelor of Public Administration have no interest on their job. It could be due to a weak desire, laziness or shyness, and it could be due to lack of self-esteem and self-confidence. In some cases of the graduates, the reason is physical or mental problem which requires professional help. Motivation and enthusiasm manifest as desire and interest, and as a driving force that pushes them to take action and pursue their goals.

This based on the data gathered in this study, which traced the 2011-2013 graduates of Bachelor of Public Administration of Kalinga-Apayao State College in Philippines.

\section{Findings}

The impact findings of the study as to the profile of the graduates from 2011-13 is procured in the succeeding matrix. 
Seven or $35 \%$ of the 14 employed graduates of 2011 are working in the Public sector, the same number of graduates who works with private institution.

Graduates of 2012 working in public composed of $22.72 \%$ or 5 out of 22 a graduate which has the same percentage with those who works in private institution.

The graduates of 2013,6 or $19.35 \%$ of them are working in the public sector while 11 or $35.48 \%$ are in the private.

Forty one percent or 41 out of 73 graduates of the graduates from 2011-2013 are working both in public and private sector.

The 2011 graduates who work as permanent are 3 or 15\% while the casuals are just the same and 8 or $40 \%$ worked as contractual.

Graduates of 2013, 7 or $22.58 \%$ are working as casual, and 10 or $32.25 \%$ are working as contractual.

The graduates of 2011,2 or $10 \%$ of them passed the civil service examination while the graduates of 2012 are 1 or $4.54 \%$ passed the NAPOLCOM examination.

The job-hunting period of 2011 graduates, there are 3 or $15 \%$ who were able to find job below 1 year after graduation while there are 9 or $45 \%$ who are able to secure job 1 year to below 2 years after graduation. Lastly, there are 2 or $10 \%$ of the graduates who was employed after three to four years after graduation.

\section{Profile of the Graduates of Bachelor of Public Administration from 2011-2013}

The Table 8 shows that 42 or $56.16 \%$ of the respondents are employed in both public and private institutions and 5 of them are permanent. Thirteen (13) were casual and 23 works as 23 contractual, $43.84 \%$ of them are unemployed but some of them pursued graduate studies and some manages their own businesses.

Table 8. Summary

\begin{tabular}{|c|c|c|c|}
\hline Year Graduated & 2011 & 2012 & 2013 \\
\hline Number of graduates & 20 & 22 & 31 \\
\hline \multicolumn{4}{|l|}{ Sex } \\
\hline Male & 6 & 10 & 15 \\
\hline Female & 14 & 12 & 16 \\
\hline \multicolumn{4}{|l|}{ Type of Occupation } \\
\hline Public & 7 & 5 & 6 \\
\hline Private & 7 & 5 & 11 \\
\hline \multicolumn{4}{|l|}{ Status of Employment } \\
\hline Permanent & 3 & 2 & 0 \\
\hline Casual & 3 & 3 & 7 \\
\hline Contractual & 8 & 5 & 10 \\
\hline \multicolumn{4}{|l|}{ Government examination passed } \\
\hline Civil Service Examination & 2 & 0 & 2 \\
\hline Napolcom & 0 & 1 & 1 \\
\hline \multicolumn{4}{|l|}{ Job Hunting period } \\
\hline Below 1 year & 3 & 7 & 12 \\
\hline $1-2$ years & 9 & 3 & 5 \\
\hline 3-4 years & 2 & & \\
\hline
\end{tabular}

The study further reveals 20 or $48 \%$ of 73 respondents are able to secure job right after graduation. While 18 or $43 \%$ got employed 2 years after graduation.

\section{Factors Affecting the Employment of the Graduates of Bachelor of Public Administration}

The study revealed that the respondents perceived that indicators "Eligibility", "Work experience related to the job" and "agency preferences" got a weighted mean of 2.20 which fall under the descriptive equivalence of "moderately affected".

\section{Conclusion}

Conferring to the results mentioned above, the majority of the graduates are employed. Only a few graduates were able to pass government examinations. The three indicators, which are "Interest on the job" and "agency preferences," were perceived as the "much affect" factor on the employment of the graduates. 
The graduates of Bachelor of Public Administration have to enroll in review classes, especially for Civil Service examination and other government examination for them to acquire job eligibility. They have to attend seminars, training, and workshops aligned to their field of interest to have more orientation on the agency they prefer for employment. They will further their studies by enrolling in their Master of Public Administration to strengthen/enhance their educational qualification that may add better opportunity for employment.

\section{References}

1) Gicana R, Sapulmaryo S, Penetrante MO. Tracer Study for the CPU College of Computer Studies Graduates from 2001 to 2005. 2001. Available from: https://www.academia.edu/4172270/.

2) Awis G. Alumni Directory Kalinga-Apayao State College 1988-2014. 1988. Available from: http://gg.gg/kascgts.

3) Michael Cosser, Graduate Tracer Study. CMO No. 06, s. 2010. Policies and Standards for Bachelor of Public Administration (BPA) Program. . Available from: https://ched.gov.ph/cmo-6-s-2010/http://www.ilsdole.Gov.ph/PAPs/ResCon/rcon_03ens1.htm. 